\title{
RELIGIOUS EDUCATION MODEL FOR CHILDREN AGE OF PRE SCHOOL IN FAMILY MELAYU SAMBAS
}

\author{
Adnan Mahdi \\ Faculty Tarbiyah, \\ Sultan Muhammad Syafiuddin Sambas Institute of Islamic Religion (IAIS), Indonesia \\ (Email: ngahadnan@gmail.com)
}

Accepted date: $13-03-2019$

Published date: 08-07-2019

To cite this document: Mahdi, A. (2019). Religious Education Model for Children Age of Pre School in Family Melayu Sambas. International Journal of Education, Psychology and Counseling, 4(31), 333-349.

DOI: $10.35631 /$ IJEPC.4310029

\begin{abstract}
This article focuses on the model of preschool education of preschool-aged children in Sambas Malay family. The purpose of this study was to find the model of preschool education of preschool children in Sambas Malay. The research was conducted in Sambas District, West Kalimantan Province. An in-depth study is directed to aspects of preschool educational goals, preschool educational programs, preschool education process, and evaluation of preschool education. This research is designed with a qualitative approach using penology method. The result of analysis shows that 1) The purpose of religious education of preschool children in Sambas Malay family there are three kinds, namely ideal goal, intermediate goal, and immediate goal; 2) Preschool program of preschool education in Sambas Malay family there are three aspects, namely: Aqidah, worship, and morals; 3) The process of religious education of preschoolers in Sambas Malay family is seen from three aspects, namely method, learning source, and time used to educate children. The method used by parents there is three kinds, namely demonstration, point of pronunciation, and show behavior. Learning resources used include Picture storybook, Iqra ', prayer book, al-Qurân, pictures, posters, mobile phones, televisions, laptops, VCDs, and children's toys. While the time spent educating children is all of the spare time that parents have, especially after Maghrib prayers and at bedtime; and 4) Evaluation of religious education used by Sambas Malay parents in educating preschool children is direct evaluation and indirect evaluation.
\end{abstract}

Keywords: Model of Religious Education, Pre-schooler

\section{Introduction}

Crisis characternation experienced Indonesian today is one indicator of the success of education implemented yet. Such a judgment is pronounced by many observers and experts of education in Indonesia, because education implemented have been unable to form the character of the nation is better (Doni Koesoema Albertus, 2007). One of the causes according to Ketut Sumarta, since national education tends to emphasize the intelligence establishment thinking (cognitive) of the sense of intelligence, with favor even innate intelligence. As a result, humans 
brained born smart, but do not have the intelligence of the mind, is still very dependent, not independent and cannot be independent (Ketut Sumarta, 2000). Human resources including human types that are difficult succeed in the workplace or community. This is consistent with studies Daniel Goleman (1995), that a person's success turned out to be $80 \%$ of which are influenced by emotional intelligence, social intelligence and spiritual intelligence, only $20 \%$ was determined by the intellect. Even with the success of the work, intellect only accounted for 4\%. Daniel Goleman further asserted that the intellectual cannot work optimally without sustained emotional intelligence, social and spiritual intelligence. Goleman explains, emotions become an engine of an action (Daniel Goleman, 2007).

Based on the opinion of Goleman above, then it should be in the implementation of priority education is not only cognitive aspects, but also affective and psychomotor aspects related to emotional intelligence, social and spiritual. The negative implications of the educational orientation error can create a mental child who feels 'stupid' since attending school. Worse yet, with a system, ranking children who are under the order of 10 really felt 'stupid' and lost confidence. If this trend continues, it will grow easily discouraged mentality, lack of confidence, and stress. Prolonged Meanwhile, in adolescence, such circumstances are usually pushed to the negative behavior. Not surprisingly, the results of education to the curriculum above, has given rise to behaviors that easily brawl teens, involved in criminal acts, dropout, corruption, manipulation, and lack of shame. Even the act which was considered embarrassing it can become a habit in their daily lives. (Williams\& Ratna Megawangi in Adnan, 2011).

Therefore, in order to be successful and can give birth education human and religious character, in addition to improving the curriculum and learning orientation, the government should hold families and communities in achieving educational goals. Family as the first and primary education must first instill morals based on the value of religion to children. While school plays as a child's potential development, while community acted as a place of maturation and maturation of the child's personality. Third of the education center, means the moral education of children in families is very important and cannot be ignored. There is a reason that shows the importance of education in the family, among others:

1. Basic child behavior and habits instilled in the family.

2. Kids absorb the customs and behavior of his parents by imitating or follow along with a sense of satisfaction.

3. Education family runs a natural, natural and engineered.

4. Family education can take place with love and sincerity.

5. The family is the first unit in the community, where the relationship is in it, most of the relationships are more direct.

Based on the above reasons, it is clear in the family education is essential for shaping the character of children. The results of the study conducted Bloom, Osborn and White of the University of Chicago, USA (1965) have concluded that the child's development occurs very rapidly in the early years of life. Empirical data show that as many as $50 \%$ of the variability of the intelligence of adults have occurred during the 4-year-old child, and a subsequent increase of about $30 \%$ occurred during the 8 -year-old boy, and then the remaining approximately $20 \%$ were over the age of 20 years. Results of research Bloom et al. showed that stimulation of learning in children of preschool age have contributed and experience were invaluable to the growth and development of children in the later period. (Faisal Jalal, 2003). 
Awareness of the importance of education of preschool children, especially Islamic religious education reflected in Sambas Malay family life in the past. A wife who is pregnant by abstinence or prohibition from doing things that are not good, such as anger, cursing, lying, crudely speaking, dreamy, lazy, sleep, immodest dress, eat and drink that is not kosher, and so on. The husband and wife are also prohibited from slaughtering animals, sad, tied a cloth towel or the like on the neck, eating cow leather, stingray skin, sour eggplant and bamboo shoots. When out night, had to bring pekaras as nails, machete or the like, carrying puntongan a wooden remaining ember and wearing a Tapeh. black After birth, boys and girls in adzankan diiqamatkan. During the swing, children are always put to sleep with blessings or dhikr lâilahaillallah. When the child has been able to communicate with parents, children begin to be educated by various restrictions, such as not allowed to eat sugar cane at sunset (sarap malam), not allowed to sleep at the time of Maghrib (sarap malam), should not sit or stand in front of the patio doors of the house, should not sew at night, not to be bertelungkup on the floor, should not be outdoors in the Maghrib prayer time, should not cut nails or hair at night, and so forth. In addition, parents also educate children how politeness when speaking and behaving to the elders, including his parents. (Supriyadi, 2010).

But unfortunately, the values that are taught superior parents to their children on top of becoming obsolete. Weaknesses Sambas Malay parents today lies in their lack of ability to transform superior value through religious education to children of preschool age. Therefore, the apparent today, most parents entrust their children to the caretakers of religious education, teacher of the Koran, private teacher or teachers at school. Not a few parents who entrust their children's education to the grandfather / grandmother or children who are teenagers, while parents are more concerned with his job. While parents who do not work outside the home, on average have less precise notion that preschool is not the time to be educated with the knowledge of religion because children are still small and cannot be taught seriously. In addition, in the implementation of religious education, not a few parents feel confused to choose and determine the programs or materials, methods and ways of evaluating the right to educate their children so it is natural that education results are still far from expectations. Errors of contention and confusion experienced by parents above is generally caused by a low level of education in formal schools, plus less active they update the knowledge of religion through religious activities, such as lectures BKMT, warning Islamic holidays, or religious sermons on television. This condition is exacerbated by low reading in the family parent's Malay Sambas, because tradition is a tradition developed in the community speak (like poems, rhymes, stories and other) and not read or write.

Based on the above issues, as a result of religious education from parents to children of preschool age is not optimal. Things like this are already underway in quite a long time, so often there are all kinds of criminal cases committed by the present generation, degradation, moral, divorce and other cases. Based on the above issues, this paper focuses on discussing while offering "model of religious education of preschool children in the family Melayu Sambas".

\section{Urgency Preschooler Religious Education in Family}

Given the importance of education to human, then everyone should get it, good education in the family, school or community education. Accumulation of three education centers that are forming the concept of lifelong education or lifelong education. It must be realized that the first education center and is the basis for education in the next two centers are family. Family regarded as an intermediary institution, that is an educational institution that can bridge the disconnect between the private sphere and the public. (Syafinuddinal-Mandarin, 2004). All 
family matters are private sphere, but the success of family management will be an important asset for the progress of society, even civilization. Therefore, the family can be regarded as the core of society, and it is already widely proven, so the success of education in the family determines the success of education in society.

Family education is an effort made by parents in providing assistance, guidance, counseling and instruction to children according to their potential through good relationships, because education in the family is seen as the education of the most highly effective and safe (Team Developer Education Sciences FIP-UPI, 2007). Small children can follow the process of education in the family safely and comfortably. As for girls, education in the home are more likely to do in a situation that is conducive. Education within the family is also more respectable and dignified (Ahmad Syalabi, 1954). This is actually a family through education for all (education for all) begins and lasts a lifetime.

Based on the above, it is clear that education in the family is very important for every child. To that end, Tafser Ahmad said there are two urgency education in the family, namely to planting value as an outlook on life that will characterize the development of the body and mind of the child; as well as a base for planting attitude in respect of teachers and knowledge in school (Ahmad Tafsir, 2008).

Education that includes three domains, namely cognitive, affective and psychomotor are generally carried out in schools, but it also applies to education in the family. The third classification domains seem to separate, but actually in the implementation of education, all three together. Education in schools assemble teaching materials covering three domains within a curriculum, while education in the family is only using hidden or curriculum hidden vitae, which is a curriculum that is not arranged in a structured and systematic such as Like in the school curriculum. In the view of Ahmad Tafsir, there are four components that should be present in a curriculum, namely: Purpose, content, method or process of teaching and learning, and evaluation. The fourth component can also be relied upon to carry out education in the home, considering that there is no theory that details the components of education in the family (Ahmad Tafsir, 2011).

\section{Research Methodology}

This study used a qualitative approach with case study design. Reasons for using a qualitative approach because in this study to explore the main focus of which is to instill the value of a school culture in creating a character education, that it is a process, events or activities of a person (some people) in revealing the substance and meaning of truth in the study, so that the necessary observations depth with a natural backdrop for understanding the phenomenon or a social phenomenon in a comprehensive and contextually to describe the empirical reality of the object under study. In accordance with the approach and the research design used, the instrument used to collect data is the researchers themselves. The presence of the researcher in qualitative research is a must. Because this type prefers research findings on observations conducted by researchers at the natural background research directly. The research was conducted in Sambas district, West Kalimantan Province. Insight study is directed at the aspects (1) the purpose of preschool education, (2) preschool education programs, (3) the process of preschool education, and (4) evaluation of preschool education.

Parents and religious leaders as the most important data sources (key informants). To determine informants, researchers used sampling (especially key informants) by purposive sampling, which later developed into other informants with the snowball technique(snowball 
sampling).To obtain the data the researchers used data collection techniques are legitimately used in qualitative research. Commonly found in qualitative research using data collection techniques such as in-depth interviews (indep tinterview), participant observation, and documentation study. Research based on observations and short interviews does not automatically be regarded as qualitative, because the task of qualitative researchers is also interpreting the beliefs and behaviors of the participants. Referring to the above opinion, the primary data collected will be analyzed by an interactive model of Miles \& Huberman following instructions: (1) data reduction, (2) data and (3) conclusion (provisional conclusion, verification and final conclusions). (Matthew B. Miles and Huberman A.Michael, 1994).

To test the validity of the data obtained, the researcher using the credibility or truth value, transferability (implementation of the application), dependability (consistency), and confirmability (objective or neutrality). (Djaman Satori and Aan Komariah, 2009).

\section{Model of Religious Education for Preschooler}

\section{Interest Religious Education Preschool Children}

Under exposure to the research data, the general purpose of religious education for preschool children in the family Melayu Sambas is to introduce, provide insight, embed, and familiarize preschool children with the teachings and values Islam contained in Sambas Malay tradition as a provision of his life experience and guidelines in the future. Through the religious education, parents are expecting him to be a pious child who obey and honor their parents and teachers, can keep muru'ah family, as well as useful to society and religion. When exposure data and general formulation is formulated specifically, will obtain the three objectives of religious education of preschool children in the family Melayu Sambas. Three of these objectives is an ideal destination, intermediate objectives and immediate objectives.

These three objectives are interrelated, meaning that the ideal goal or ideal goal can be achieved if the intermediate objectives and goals once achieved, intermediate objectives or intermediate goal can be achieved if the goal once been reached, and the purpose of summary or Immediately goal has been reached when the material being taught has been known, preschoolers understood and practiced in daily life. The ideal goal of religious education of preschool children in the family Melayu Sambas are: Establishment of a noble character according to religious teachings and values of Islam which has been a tradition in the family life of Malay Sambas. The formulation is said to be an ideal destination for all the research informants wants their children to be pious or shalehah shown with the knowledge and practice of religion, could keep family muru'ah, useful to society and religion, and has provision for the life of their afterlife. While the goal or between intermediate goals religious education for preschool children in Sambas Malay family was a goal that cannot be seen or proven directly when education was implemented. The purpose of this will be seen when the child passes the age of preschool, or minimal after several years have passed. The purpose of question is as follows:

a. child is able to maintain muru'ah family and useful to society, nation, and religion.

b. Kids have the knowledge and experience to implement the teachings of Islam as the provision of education in schools (RA / kindergarten, elementary, and so on).

c. Preparing the ground of religion as a fortress to ward off the negative effects of social environment, science and technology.

The immediate purpose or goal Immediately religious education of preschool children in the family Melayu Sambas is a goal that can be viewed immediately or directly by parents who 
educate their children. Instantly here is not only meaningful when it is alone, but also for the educational process takes place at the age of preschool children. Objectives instantly question is:

a. Knowing basic and values of Islam. Basics of Islam as knowing God as the creator of the universe, knowing the Koran as a holy book of his religion, knowing Muhammad as a prophet, knowing the obligations and restrictions on religion, and so forth. While the values of Islam as knowing and feeling the love of parents, the importance of togetherness, the magnitude of benefit sharing, the obligation to respect and obey their parents, as well as other Islamic values.

b. The establishment of an Islamic character as a child can pray, read a verse from the Qur'an, fasting, praying, greeting and shaking hands, sharing, respect and obey their parents, courtesy to those who are older and to playmates and other Islamic code.

Objectives instantly is associated with a program that is delivered, for example, the parents teach children to read the Quran, then at the same time or in the time span is not long children can mention the letters of the Koran have been taught, and as this is called destination instantly or Immediately goal. Knowledge of the children read the letter hijaiyah will continue to develop in accordance with the education provided, and in time when the child is enrolled in school and is able to read the Koran, then at this stage the child has reached the so-called second phase of interest between the destination or intermediate goal. After the goal immediately and between achieved, then the potential and ability of the child growing in line with the educational and additional experience which has been accepted in schools and communities, so that children become used to implement the teachings of religion and showed good character according to the teachings of Islam and Islamic values living in cultures society, the ideal goal or ideal goal can be said to have been achieved.

The achievement of the ideal goal of true religious education based on the parents' education since preschool and secondary education in the family, but the achievement cannot be maximized if not supported by education and experience gained in the school and community. To that end, the goal of an ideal Islamic religious education in Sambas Malay community is the aim achieved by the accumulated achievement of the objectives of education in the family, school, and community. Objectives such as this is called an ideal destination, or it could be called an integral goal of religious education. Human figures that have reached the ideal goal of religious education in the formulation and understanding Ahmad Tafsir called the Sambas Malay Muslim parents are perfect. When simplified figure of the perfect Muslim in the context of preschool children are obedient son implement the teachings of religion, filial to parents, and useful in society. The characteristics of the perfect child is actually no different from the concept of a perfect man in the view of Ahmad Tafsir. The reason, the obedient son implement religious teaching is that children who take piety to Allah alone. While filial to parents is child healthy and strong body, because it is not likely the children were not strong, healthy, and do not have the skills to serve up to his parents. As for the children who can be useful for families and communities are children who have the intelligence and skill, because armed with two such capabilities, the child will be able to resolve the problem of life according to age and ability.

\section{Preschool Children Religious Education Program}

Based on data research, known religious education program of preschool children in the family Melayu Sambas basically have the same for each age range, from birth until the age of 72 months, which differ only how to teach it. From the description of the data, it can be classified as religious education programs for preschoolers in Sambas Malay family. As for the religious education program classification is to be detailed in the table below: 
Table 1: Religious Education Program Preschool Children in Malay Sambas Families

\begin{tabular}{|c|c|c|c|}
\hline \multirow[b]{2}{*}{ No } & \multirow[b]{2}{*}{ Age } & \multicolumn{2}{|r|}{ Education Program Preschool Children Religion } \\
\hline & & $\begin{array}{c}\text { Categor } \\
\mathrm{y}\end{array}$ & Indicator \\
\hline \multirow[t]{3}{*}{1} & \multirow[t]{3}{*}{$\begin{array}{c}0-12 \\
\text { Mont } \\
\text { hs }\end{array}$} & $\begin{array}{l}\text { aqidah } \\
\text { (faith) }\end{array}$ & $\begin{array}{l}\checkmark \text { Allowing a child to hear the sentence tayyibah, such } \\
\text { as the call to prayer, iqamah, asthma God through } \\
\text { nasyid, and prayers, and the verses of the holy } \\
\text { Quran } \\
\checkmark \text { gives toys such as pictures or pieces of letters } \\
\text { hijaiyah }\end{array}$ \\
\hline & & $\begin{array}{l}\text { Worship } \\
\text { (Islam) }\end{array}$ & $\begin{array}{l}\checkmark \text { Allowing children to watch and observe parents } \\
\text { praying } \\
\checkmark \text { Allowing children to watch and see images of } \\
\text { people praying and prayer } \\
\checkmark \text { Taking the child on the side of parents who were } \\
\text { praying }\end{array}$ \\
\hline & & $\begin{array}{l}\text { Morals } \\
\text { (Ihsan) }\end{array}$ & $\begin{array}{l}\checkmark \text { Say hello to the new child waking } \\
\checkmark \text { Provide child to eat using the right hand } \\
\checkmark \text { Feeding a child while sitting } \\
\checkmark \text { shook the hands of children } \\
\checkmark \text { Calling a child, a voice full of affection } \\
\checkmark \text { Talking, dress, behave and be good in front of the } \\
\checkmark \text { Reading BASM ne and prayed with allowable } \\
\quad \text { child's voice heard at time of eating, drinking, or } \\
\quad \text { feed her }\end{array}$ \\
\hline \multirow[t]{3}{*}{2} & \multirow[t]{3}{*}{$\begin{array}{c}13-24 \\
\text { Mont } \\
\text { hs }\end{array}$} & $\begin{array}{l}\text { aqidah } \\
\text { (faith) }\end{array}$ & $\begin{array}{l}\checkmark \text { Allowing a child to hear verses of the Koran, God } \\
\text { asthma, and shalawat } \\
\checkmark \text { Introducing letter forms hijaiyah } \\
\checkmark \text { Guiding children to read basmalah } \\
\checkmark \text { Fostering love to hear dhikr of Allah (Allahu Allah, } \\
\quad \text { Lailahaillallah,creed, and dhikr others) through the } \\
\quad \text { chanting when putting the child } \\
\checkmark \text { Introduce fasting with a child to break the fast }\end{array}$ \\
\hline & & $\begin{array}{l}\text { Worship } \\
\text { (Islam) }\end{array}$ & $\begin{array}{l}\checkmark \text { Allowing a child sees a parent prayer, or adhan on } \\
\text { TV etc. } \\
\checkmark \text { inviting (preamble) of the children to pray } \\
\checkmark \text { Starting to teach children the movements of prayer } \\
\quad \text { and azan }\end{array}$ \\
\hline & & Morals & $\checkmark$ teach children to shake hands with parents and \\
\hline
\end{tabular}




\begin{tabular}{|c|c|c|c|}
\hline & & (Ihsan) & $\begin{array}{l}\text { family members } \\
\checkmark \text { Showing affection of parents with a soft touch and a } \\
\text { voice full of affection (pet) } \\
\checkmark \text { teaching children to share toys his brother } \\
\checkmark \text { Reading basmalah and pray before feeding or } \\
\quad \text { feeding } \\
\checkmark \text { Training children during a visit to say hello and } \\
\quad \text { shake hands with others } \\
\checkmark \text { teach children to speak a good word, such as how to } \\
\quad \text { borrow toys } \\
\checkmark \text { Allowing children to eat with your right hand }\end{array}$ \\
\hline \multirow[t]{3}{*}{3} & $\begin{array}{c}25-36 \\
\text { Mont } \\
\text { hs }\end{array}$ & $\begin{array}{l}\text { Aqeedah } \\
\text { (faith) }\end{array}$ & $\begin{array}{l}\checkmark \text { Inviting children shalawat, read basmalah, and pray } \\
\text { with guided } \\
\checkmark \text { Familiarize children hear the Divine Name, asthma } \\
\text { God and verses of the Koran } \\
\checkmark \text { Start introducing letters hijaiyah } \\
\checkmark \text { Starting to teach rote prayer and short chapters by } \\
\quad \text { way of guided } \\
\checkmark \text { Allowing a child to ask God when asking for } \\
\text { something to parents through reading and praying } \\
\text { basmalah } \\
\checkmark \text { Start introducing nature around as a creation of God }\end{array}$ \\
\hline & & $\begin{array}{l}\text { Worship } \\
\text { (Islam) }\end{array}$ & $\begin{array}{l}\checkmark \text { Teach prayer movement } \\
\checkmark \text { Inviting children prayers to the mosque, listening to } \\
\text { lectures in mosques as efforts to foster a sense of } \\
\text { love for the mosque } \\
\checkmark \text { out to eat sahur during Ramadan }\end{array}$ \\
\hline & & $\begin{array}{l}\text { Morals } \\
\text { (Ihsan) }\end{array}$ & $\begin{array}{l}\checkmark \text { took her shaking hands and kissing the hand of a } \\
\text { parent as a manifestation of an attitude respect and } \\
\text { courtesy } \\
\checkmark \text { Teach invoke an older brother in the traditions of } \\
\text { the Malay community, such as Kak Long, Kak } \\
\text { Ngah, etc. as a form of respect for the younger } \\
\text { children to older } \\
\checkmark \text { Advise children not to take other people's stuff } \\
\text { without permission } \\
\checkmark \text { Reprimand of the child's attitude when he was } \\
\text { angry, sulk, or blame the parents } \\
\checkmark \text { Getting used to say hello during a visit or enter } \\
\checkmark \text { Teach children to wear clothes that cover the aurat } \\
\text { to buy clothes a Muslim / Muslim }\end{array}$ \\
\hline
\end{tabular}




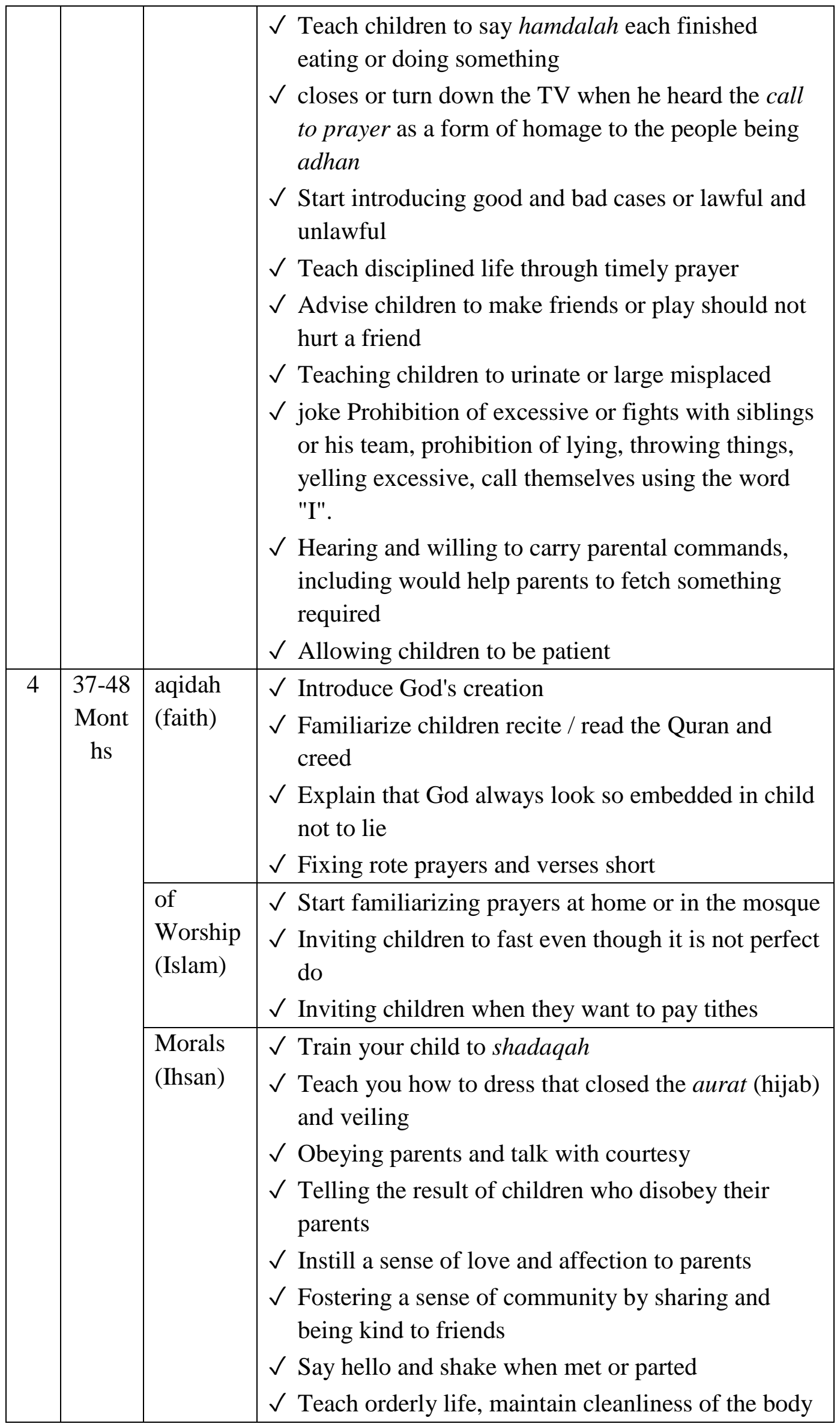




\begin{tabular}{|c|c|c|c|}
\hline & & & and clothing, maintain health and behavior (morals) \\
\hline \multirow[t]{3}{*}{5} & \multirow[t]{3}{*}{$\begin{array}{l}49-60 \\
\text { Mont } \\
\text { hs }\end{array}$} & $\begin{array}{l}\text { aqidah } \\
\text { (faith) }\end{array}$ & $\begin{array}{l}\checkmark \text { Improving reading basmalah } \\
\checkmark \text { Guiding children to read prayers, letters hijaiyah } \\
\text { and shalawat } \\
\checkmark \text { chamber recitals Inviting children taklim } \\
\checkmark \text { Start explaining the existence of God, heaven and } \\
\quad \text { hell }\end{array}$ \\
\hline & & $\begin{array}{l}\text { Worship } \\
\text { (Islam) }\end{array}$ & $\begin{array}{l}\checkmark \text { Salah Maghrib, Isha and Friday congregational } \\
\checkmark \text { Train children to fasting and paying tithes } \\
\checkmark \text { Train children to perform ablution properly } \\
\checkmark \text { Teach prayer movements correctly }\end{array}$ \\
\hline & & $\begin{array}{l}\text { Morals } \\
\text { (Ihsan) }\end{array}$ & $\begin{array}{l}\checkmark \text { Familiarize children clean life } \\
\checkmark \text { Saying greeting each entered the house } \\
\checkmark \text { Respecting parents and elder people } \\
\checkmark \text { shun the attitude of envy with playmates } \\
\checkmark \text { Train children are accustomed alms } \\
\checkmark \text { Prohibit children to steal or say no politely with } \\
\text { parents }\end{array}$ \\
\hline \multirow[t]{3}{*}{6} & \multirow[t]{3}{*}{$\begin{array}{c}61-72 \\
\text { Mont } \\
\text { hs }\end{array}$} & $\begin{array}{l}\text { aqidah } \\
\text { (faith) }\end{array}$ & $\begin{array}{l}\checkmark \text { Allowing children to read the Quran through learn } \\
\text { the Koran } \\
\checkmark \text { Memorizing prayers and short verses } \\
\checkmark \text { teach writing letters hijaiwell } \\
\checkmark \text { Inviting come to the recitation or assembly's dhikr } \\
\checkmark \text { basmalah Familiarize read and pray when you start } \\
\text { learning other / } \\
\checkmark \text { Growing devotion to the Prophet through } \\
\text { documentary }\end{array}$ \\
\hline & & $\begin{array}{l}\text { Worship } \\
\text { (Islam) }\end{array}$ & $\begin{array}{l}\checkmark \text { Inviting children five daily prayers in congregation } \\
\text { at home or at the time of Maghrib, Isha and Friday } \\
\text { congregation at mosque }\end{array}$ \\
\hline & & $\begin{array}{l}\text { Morals } \\
\text { (Ihsan) }\end{array}$ & $\begin{array}{l}\checkmark \text { Introduce commands and prohibitions of Allah or } \\
\text { the problem of clean and unclean } \\
\checkmark \text { Remind children not to lie with parents } \\
\checkmark \text { Allowing a child to do good } \\
\checkmark \text { Familiarize greetings } \\
\checkmark \text { Familiarize shake hands when meeting or parting } \\
\checkmark \text { Getting used to share, such as sharing food with } \\
\text { other friends } \\
\checkmark \text { Preventing child to lie with parents }\end{array}$ \\
\hline
\end{tabular}




\section{Preschool Children Religious Education process}

Based on exposure and analysis of research data, can be detailed that the religious education process undertaken by parents to their children in the preschool years is the Sambas Malay family in three ways, namely shows a sense, pronunciation and shows a show a behavior. Show the taste is affection shown to her parents in giving Islamic religious education in preschool children. Form of affection in the form of smiles, caresses, kisses, hugs, attention, and greetings to children. From demonstrations of affection, children will feel the warmth of love and affection from his parents so that he feels safe, quiet, and full of excitement. While shows the pronunciation is religious education conducted by singing children at bedtime, led him to read prayers before and after meals, guide the children memorize a prayer / short chapters, give warning, advice, said the advice / stories that are useful for the good and smartness morals of children, through this wording shows, children feel guided studying religion while in the house.

The tujuk behavior is religious education is done by showing the behavior or examples right to the child, as exemplified eat right handed, ablutions, the examples do prayer movement, showing exemplary praying, fasting, the spoken word, in politeness, etc. In addition, the time to uphold discipline, firmly behave teachable moments, including punishment to children who make mistakes are also included in the shows sold. Through this behavior shows, children see firsthand how to perform religious practices and can emulate parents in enforcing discipline or a firm stance in providing education at home.

Specialized in punishment, there are three ways that parents do Melayu Sambas in educating their children, namely punishment by way of scaring, punishment by threats and punishment by pinching, tweaked (pull / twist the ear), and hit (tappek, pappah, rimpat). Each kind of penalties adapted to the small magnitude of the error committed by the child.

As for the time spent to educate preschoolers in Sambas Malay family is all leisure and religious education are focused generally done after Maghrib prayers. While the sources used vary widely, depending on the ability of each parent. The sources can include picture books, posters, books Iqra ', the Koran, mobile phones, televisions, laptops and children's toys. Through learning resources, parents be helped in providing religious education to children of preschool age.

\section{Evaluation of Preschool Children's Religious Education}

Based on the exposure and research data, it can be explained that the way that Sambas Malay parents use in evaluating the preschool education of preschool children there are 2 kinds, namely direct (direct) and indirect (indirect). Direct way is the evaluation done directly by husband or wife after he gave religious education to his son at home. Direct evaluation begins with the process of seeing and observing the potential development of children, providing religious programs according to the needs of the child, reviewing the mastery of the material that has been taught, improving and completing the taught material, getting used to repeating to become his deeds in everyday life. While indirect evaluation is done by discussing between husband and wife or with others (grandfather, grandmother, or expert) about potential, development, and expectation of parent to child ability in religious education field.

\section{Model Offerings}

Based on the above description and analysis, a model of religious education for preschoolers in Sambas Malay family is required. As for the offer of a model of religious education that is predicted to effectively print a perfect Muslim in preschool children in the Sambas Malay family is: 


\section{Figure 1: Design Process Creating a Religious Education Model for Preschool Children in Sambas Malay Families}

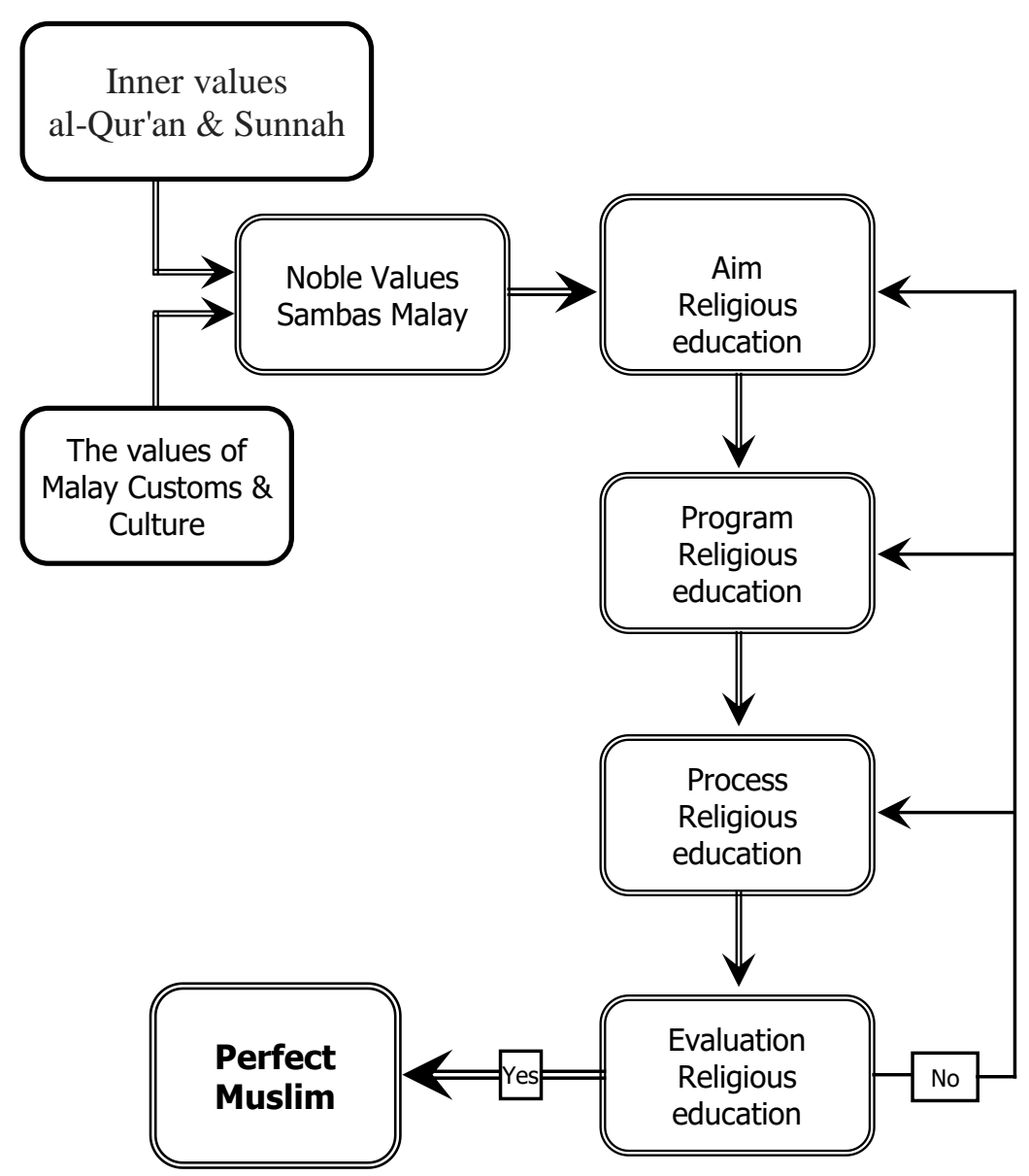

Based on the picture above, it can be explained the draft of making a conceptual model of religious education for preschoolers in Sambas Malay family as follows:

a. The noble values (local genius) of Sambas Malay originate from the values contained in the Qur'an and Sunnah of the Prophet (s) and the values contained in the Malay culture and Sambas.

b. The noble values of Sambas Malay became the foundation and reference for parents in formulating the goals of religious education for preschoolers in Sambas Malay family.

c. From the formulation of these objectives, hereinafter translated into religious education programs for preschoolers in Sambas Malay family.

d. After the program is realistically based on current life demands and predictions of future challenges, then the program is implemented in the preschool process of preschool education in Sambas Malay family.

e. The next stage is to evaluate the educational programs and processes to find out the results of the education. If the results of the evaluation show that the goal of religious education has not been achieved according to expectations, then the parent should make feedback on the process, program and educational goals to correct the 
errors or deficiencies found. This feedback activity is done repeatedly until the goal of religious education of preschool children in Sambas Melayu family is achieved according to the expectation of parents, namely the formation of the child becomes a perfect Muslim

\section{Implementation of Religious Education Model}

Based on the explanation of the above model, this stage is a way of implementing the model to be a guide in providing preschool education for preschool children in Sambas Malay. Before explaining the stages of implementation, it should be said that the model offered is named: The Model of Religious Education of Preschool Children in Sambas Malay Family ". After that, below will explain the mechanism of implementation of religious education model of preschool children in Sambas Malay family as follows:

a. Parents should have a clear religious education objective while educating preschoolers in the Sambas Malay family. These goals are ideal goals (long-term), intermediate (medium-term) and immediate (short-term) objectives.

b. The formulation of religious education goals of preschoolers is further elaborated in the education program, covering three aspects, namely aqidah (belief), worship (Islamic), and aspects of morals.

c. The ready-made program, implemented in religious education activities using three common methods, namely demonstration, point of pronunciation and performance.

d. After the process of religious education is implemented, then parents should evaluate the religious education activities that have been done. There are two types of evaluation activities, namely direct evaluation and indirect evaluation. Direct evaluation can be done through the stages, such as seeing and observing the potential development of children, providing religious education programs that meet the needs of children, reviewing the mastery of the material that has been taught, improve and complement the taught material, get used to repeat the practice of children in life daily. While indirect evaluation is done by discussing between husband and wife or with other people (grandfather, grandmother, or expert) about the potential, development, and ability possessed by the child after being taught religious education material. If the results of these two types of evaluations indicate that the expected goals of the parents have not been reached, then the parent should make feedback starting from the process, program and educational goals to correct the deficiencies / errors found. Feedback activities are done repeatedly until the goal of religious education of preschool children in Sambas Malay family has been achieved according to the expectation of parents, namely the formation of the child become a perfect Muslim with three characteristics: Religious, have a noble character, and useful in the life of the community.

The flow of implementation of religious education model of preschool children in Sambas Malay family can be illustrated as follows: 
Figure 2: Bid Implementation of Religious Education Model Preschool Children in Sambas Malay Families

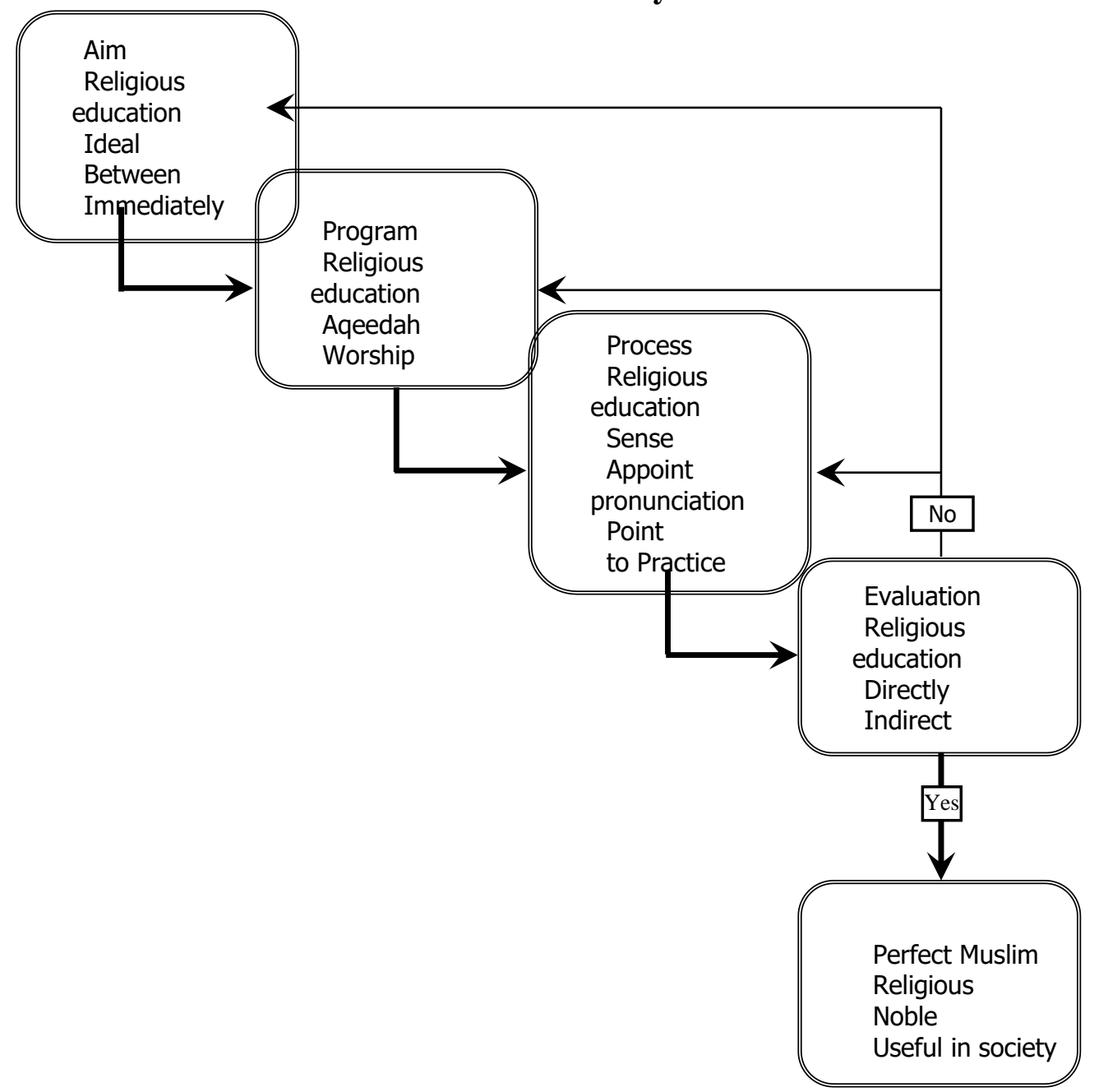

\section{Assumptions}

After explaining the stages of implementation of the religious education model of preschool children in Sambas Malay family above, the following will be presented several assumptions as follows:

\section{Parental Ability}

Implementation of religious education model of preschool children in Sambas Malay family is in great need of parent ability, especially on education level aspect and knowledge to take care and care for children properly. The educational background of parents at least graduated MA / SMA equivalent and have a strong desire to understand how to educate and care for children, either through reading books, training and seminars, and willing to emulate the success of parents or ancestors in providing religious education to their children. In addition, parents must have a high religious awareness, such as being able to read and practice the teachings of the Qur'an, has a noble character, and so forth. Because, without the support of the parent (husband and wife), the model of religious education offered will not work optimally.

\section{Family Economics}

The application of this model of religious education must also be supported by a sufficient 
family economy, in the sense of sufficient food, sufficiently clothing, and sufficient boards. If one of these basic needs cannot be met, then this model will be difficult to implement properly. For example, because of lack of food that demands parents to work all day in the fields, consequently the child's education is neglected. In other contexts, for example, learning resources do not exist due to lack of economic ability, of course it can affect the implementation of religious education so that the application of this model will be less effective.

\section{Education Environment}

Environment is a part that cannot be separated with education, including family education. The model offered above cannot be detached from the environment when implementing it. The environment in question is the environment in the family and environment outside the family / community. To optimize the implementation of the model offered, the parents need to create a religious family environment, meaning that parents should be role models in the practice of religious teachings and values, such as examples of worship, exemplary attitude, speech and morals. Exemplary will be a "teacher" is very memorable in the eyes of children. Similarly, with other family members, they should be good role models for preschoolers.

In addition to the environment in the family, the environment around the house and the community should also be a good example for preschoolers. But the problem is, to create a good environment outside the family is certainly difficult to do, therefore when the couple will establish a new home, the main option that must be considered is the environment of the house is good and healthy. For parents who are already in the unfavorable environment, then the supervision and assistance to the child should be more leverage, so that every attitude, words, and behavior that is not good can be immediately filed by parents for their children.

\section{Excess Model}

The model of preschool education of preschoolers offered is born from the "womb" of the Sambas Malay family. His notions are based not only on the current reality of Malay family life, but also referred to cultural customs in educating preschool-aged children who have been tradition from Sambas Malay figures. Because the model offered is the result of the past and present facts, the advantages can be used for all Sambas Malay parents who have preschool children in the present and future. If the assumption that Melayu Sambas is true as the Malay homeland as described earlier in this chapter, then this model of religious education can be used for Malay parents in Indonesia and countries that still share the same cultural and cultural characteristics.

\section{Model Limitations}

Based on the data, the results of the analysis and see the evidence on the Malay family that has successfully educate the religion and morals of children, it is believed that the educational model offered is effective enough used by parents who have preschoolers. However, the limitations of this model only apply to preschoolers and religious education materials programs that focus on aspects of aqidah (faith), worship (Islamic), and morals (keihsanan). Apart from these indicators, this educational model has not provided the confidence to be implemented by parents in the family

\section{Opportunities for Model Implementation}

In general, parents or brides Sambas Melayu currently have a fairly adequate education, most have completed education at the MA / SMA level. In addition, the family's economy is also improving, coupled with intensive coaching and training programs for mothers or bridal couples from local governments. Religious activities such as religious matriarchs, mosque 
lectures, lectures and religious guidance by preachers programmed by the local government, as well as the increasing number of educational institutions at MA (MAN IC Sambas) and universities (IAIS Sambas, Sambas Polytechnic, ADI Sambas) will certainly increase Human Resources in Sambas District, including ethnic Malays. Therefore, the opportunity for implementation of preschool educational model in Sambas Malay family will be more open in the future, because the required indicator will increase to be fulfilled well.

\section{Conclusions}

First, the goal of religious education of preschoolers in the Sambas Malay family is three kinds, namely ideal goals, intermediate goals and immediate goals. Ideal goal is the formation of a perfect Muslim with the characteristics: Obedient religious teachings, noble and beneficial to the community. While the Intermediate Objective is: Muru'ah awake family and useful to other human beings, knowing and willing to practice the teachings of religion as a provision of education in formal schools, and to prepare the basis of religion as a fortress to ward off the negative influence of promiscuity and the advancement of science and technology. Instantaneous purpose is to know the basic and values of Islamic teachings and embedded Islamic morals.

Second, the program of religious education materials given by parents to preschool children in Sambas Malay family generally includes three aspects, namely aqidah, worship and morals. Aspects of aqidah relating to the pillars of faith, aspects of worship associated with the pillars of Islam, and the moral aspects associated with ihsan.

Third, the process of religious education conducted by parents to educate their preschool-aged children with religious education in Sambas Malay family in terms of three aspects, namely the method of delivery, learning resources used, and time spent to educate children. The method used there are three kinds, namely rallies, point of pronunciation and show behavior. The demonstration is the affection shown by parents to their children in the family through smiles, caresses, kisses, hugs, attention and greetings. In Islamic education, the method included in the demonstration is the bil hikmah method, which is the method that emphasizes the feelings of love, compassion and wisdom. While the point of pronunciation is religious education given through singing, kicking, guidance, guidance, reprimand, advice, advice, story or story. In Islamic education, methods included in the pronunciation include: Lectures, stories and stories, mauidzah and mujadalah. While the point of behavior is religious education given through habituation, exemplary, or anything that is shown through behavior. In Islamic education, the methods included in the show behavior is the method of habituation, exemplary (uswah), ibrah (lesson), targhib and tarhib. The learning resources used include: Picture book, Iqra 'book, prayer book, al-Quran, pictures, posters, mobile phones, VCDs, televisions, laptops and toys. While the time spent educating preschoolers with religious education is all of the spare time parents have, especially after Maghrib prayer and child time before bedtime.

Fourth, the evaluation of religious education by Sambas Malay parents in educating preschool children are two, namely direct evaluation and indirect evaluation. Direct evaluation is done through stages, such as seeing and observing the potential development of children, providing religious programs according to the needs of the child, reviewing the mastery of the taught material, improving and completing the material that has been taught, getting used to repeating to become his deeds in everyday life. While indirect evaluation is done by discussing between husband and wife or with other people (grandfather, grandmother, or expert) about the potential, development and ability of the child after being taught religious education program. The results of these talks were used as consideration to improve religious education activities 
to achieve goals as per expectation of Sambas Malay parents.

\section{Bibliography}

Abdullah, Abd. Rahman, Aktualisasi Pendidikan Islam; Rekonstruksi Pemikiran dalam Tinjauan Filsafat Pendidikan Islam, Yogyakarta: UII Press, 2001.

Abdullah, Abdurrahman Saleh, Pendidikan Berdasarkan al-Qurân, Jakarta: Rineka Cipta, 1994. Adnan, Pendidikan Karakter di Sekolah, Jakarta: Sedaun Publishing, 2011.

Ahmad Tafsir, Ilmu Pendidikan dalam Perspektif Islam, Bandung: PT. Remaja Rosdakarya, 2011.

Albertus, Doni Koesoema, Pendidikan Karakter, Jakarta: PT. Grasindo, 2007.

Goleman, Daniel, Kecerdasan Emosional, terjemahan oleh T. Hermaya, Jakarta: Gramedia Pustaka Utama, 2007.

I, Ketut Sumarta, Pendidikan yang Memekarkan Rasa, Sindhunata (ed.), Membuka Masa Depan Anak-anak Kita; Mencari Kurikulum Pendidikan Abad XXI, Jogjakarta: Kanisius, 2000.

Jalal, Faisal, "Dari IQ Menuju Ragam Kecerdasan”, Buletin PADU Jurnal Ilmiah Anak Dini Usia, Jakarta: Direktorat PADU, Vol. 2, 2003.

Mandari, Syafinuddin al, Rumahku Sekolahku; Panduan Islami untuk Mencerdaskan Anak dalam Lingkungan Keluarga, Jakarta: Pustaka Zahra, 2004.

Matthew B. Miles dan A.Michael Huberman, Qualitative Data Analysis: A Source Book of New Methodes, C.A.Sage. Newbury Park, 1994.

Nurwadjah, Ahmad, Tafsir Ayat-ayat Pendidikan; Hati yang Selamat hingga Kisah Luqman, Bandung: Marja, 2010.

Satori, Djaman dan Aan Komariah, Metode Penelitian Kualitatif, Bandung: Alfabeta, 2009.

Supriadi, "Pengembangan Model Pengasuhan Anak dalam Keluarga untuk Memulihkan Sistem Nilai; Studi Kasus pada Masyarakat Melayu Sambas", Disertasi Pendidikan Islam, Bandung: PPs UPI Bandung, 2010, t.d.

Syalabi, Ahmad, Tarîkh at-Tarbiyah al-Islâmiyah, Kairo: Dar al-Kasysyaf, 1954.

Tafsir, Ahmad, ed., Pendidikan Agama dalam Keluarga, Bandung: Remaja Rosda-karya, 2008.

Tim Pengembang Ilmu Pendidikan FIP-UPI, Ilmu \& Aplikasi Pendidikan, Bandung: PT. Imtima, 2007. 